\title{
EFEKTIVITAS PEMBELAJARAN DARING PADA KONDISI WFH/WFO DI MADRASAH IBTIDAIYAH KECAMATAN REBAN
}

\author{
AWANG SUGIARTO \\ MI Islamiyah Tambakboyo Kabupaten Batang \\ e-mail : awangsugiartomi@gmail.com
}

\begin{abstract}
ABSTRAK
Penelitian ini dilatarbelakangi adanya implementasi moda pembelajaran daring di saat pemberlakuan Work From Home (WFH) dan Work From Office (WFO) di Madrasah Ibtidaiyah Kecamatan Reban. Opini yang berkembang di masyarakat menyatakan bahwa pembelajaran daring kurang efektif,karena pembelajaran daring sebelum pandemi global hanya diterapkan sebagai pendukung pembelajaran untuk pemberian tugas dan portofolio bagi peserta didik namun kondisi saat ini cenderung dipaksakan tanpa persiapan infrastruktur yang memadai menggantikan pembelajaran tatap muka. Oleh karena itu peneliti mempunyai keinginan yang kuat untuk menguji tingkat efektivitas pembelajaran dengan pendekatan kualitatif dan menggunakan desain studi kasus. Adapun pengumpulan data menggunakan wawancara dan angket. Angket disebarkan kepada 63 orang guru Madrasah Ibtidaiyah di Kecamatan Reban. Analisis data yang digunakan yaitu analisis data kualitatif. Berdasarkan hasil penelitian dengan berpedoman pada 7 indikator yang diteliti menunjukkan bahwa tingkat efektivitas pembelajaran pada kisaran $67 \%$.
\end{abstract}

Kata Kunci : Efektivitas,daring,WFH/WFO,Kualitatif

\section{PENDAHULUAN}

Implementasi Work From Home (WFH) dan Work From Office (WFO) di semua desa di Kecamatan Reban sesuai dengan Surat Edaran Sekretaris Daerah Kabupaten Batang Nomor: 800/096/2021 tanggal 2 Juli 2021 tentang sistem kerja pegawai Aparatur Sipil Negara di lingkungan Pemerintah Kabupaten Batang dan hasil Rakor pelaksanaan PPKM darurat Kabupaten Batang antara lain mengatur agar kepala Satuan pendidikan menerapkan sistem pembagian kerja guru dan TAS dengan formasi $25 \%$ bekerja di kantor (WFO) dan $75 \%$ bekerja dari rumah (WFH), dengan ketentuan kepala Satuan pendidikan dan tenaga kebersihan sekolah tetap berangkat untuk memantau dan melaksanakan pekerjaan harian dengan mengutamakan protokol kesehatan yang ketat.

Dampak penting dari persoalan krusial di atas yang dialami pendidikan di Indonesia yang juga dialami banyak negara adalah metode pembelajaran yang secara mendadak harus dilakukan secara jarak jauh atau melalui moda pembelajaran daring .

Pembelajaran daring yang dimaksudkan dalam penelitian ini adalah sistem pembelajaran yang dilaksanakan melalui perangkat Personal Computer (PC) atau Laptop dan Handphone yang terhubung dengan koneksi jaringan internet. Guru dapat melakukan pembelajaran bersama di waktu yang sama menggunakan grup di media sosial seperti WhatsApp (WA), telegram,instagram,aplikasi zoom ataupun media lainya,dengan dengan demikian guru dapat memastikan siswa mengikuti pembelajaran dalam waktu yang bersamaan meskipun di tempat yang berbeda.

Efektifitas moda pembelajaran daring dipengaruhi oleh banyak faktor antara lain kompetensi guru dalam pengelolaan pembelajaran. Pengelolaan pembelajaran pada kondisi normal sudah menjadi aktifitas yang biasa dikerjakannya namun efek transformasi mendadak yang terjadi saat ini membutuhkan solusi alternatif yang tepat dari semua guru untuk mengelola pembelajaran jarak jauh.Menurut Ma'arif ( 2011:42 ) Seorang guru merupakan salah satu komponen manusia yang mempunyai peranan penting antara lain dalam mengelola dan mewujudkan proses belajar mengajar yang kondusif dan efektif.

Kegiatan belajar mengajar yang efektif dan efisien sudah barang tentu didukung dengan penggunaan media pembelajaran.Pemilihan media yang tepat oleh guru ikut menentukan 
keberhasilan dalam penyampaian tujuan pembelajaran. Fungsi media menurut Nurdyansyah (2019:64) yaitu meningkatkan efektivitas dan efesiensi pembelajaran, meningkatkan gairah belajar siswa, meningkatkan minat belajar dan motivasi belajar, menjadikan peserta didik berinteraksi langsung dengan kenyataan dan meningkatkan kualitas pembelajarn.

Pembelajaran moda daring merupakan strategi yang paling efektif untuk mencegah terbentuknya lembaga pendidikan sebagai klaster baru penyebaran Covid-19. Hal ini yang terjadi pada sebagian besar wilayah dan lembaga pendidikan saat ini,namun tantangan utama yang dihadapi adalah ketersediaan fasilitas yang masih terbatas ,keterbatasan kemampuan peserta didik, serta belum berkembangnya budaya pembelajaran jarak jauh atau daring ,baik pada pihak tenaga pendidik maupun peserta didik. Berbagai kendala tersebut mengakibatkan sebagian masyarakat ,baik dari kalangan peserta didik ,orang tua/wali memandang strategi pembelajaran moda daring belum dapat menjadi strategi yang efektif bagi kegiatan pembelajaran saat ini oleh karena itu praktik pembelajaran daring perlu dievaluasi agar ada perbaikan-perbaikan demi terselenggaranya proses belajar yang efektif .Penelitian ini bermaksud untuk mengetahui efektivitas pelaksanaan moda pembelajaran daring di Madrasah Ibtidaiyah Kecamatan Reban .

\section{METODE PENELITIAN}

Penelitian ini menggunakan pendekatan kualitatif dengan desain penelitian studi kasus. Dipilihnya desain studi kasus untuk mengungkap fenomena yang terjadi secara alami di Madrasah Ibtidaiyah Kecamatan Reban. Pengumpulan data penelitian menggunakan metode wawancara dan angket .Kemudian analisis data menggunakan analisis data kualitatif mulai dari pengumpulan data ,verifikasi, reduksi data dan kesimpulan dengan model Miles \& Huberman (dalam Rijali 2018 : 83) menggambarkan proses analisis data penelitian kualitatif sebagai berikut.

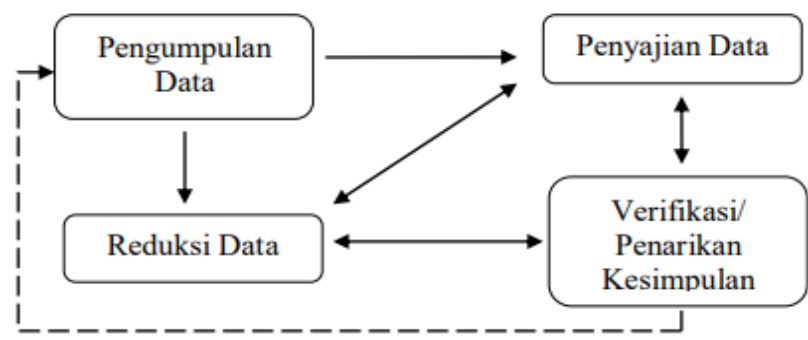

\section{Gambar 1. Proses Analisis Data Penelitian Kualitatif}

\section{HASIL DAN PEMBAHASAN}

Untuk memfokuskan hasil penelitian. Peneliti menyajikan hasil olah data kualitatif dalam bentuk diagram yang menggambarkan fenomena beberapa kasus yang terjadi sesuai indikator yang diteliti. Kemudian menguraikan pembahasan secara sistematis pada setiap indikator.

\section{Kesiapan Moda Pembelajaran daring}

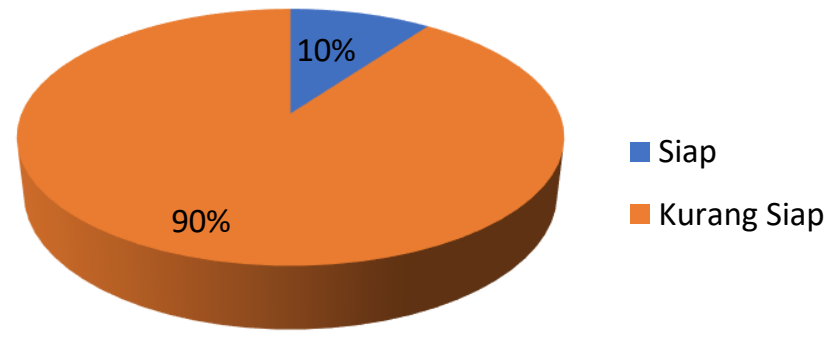

Gambar 2.Kesiapan Moda Pembelajaran daring 
Berdasarkan hasil wawancara dan jawaban angket informan diperoleh informasi bahwa hanya $10 \%$ yang siap selebihnya $90 \%$ kurang siap untuk menerapkan moda pembelajaran daring. Faktor kesiapan sangat berpengaruh terhadap pelaksanaan dan out put program pembelajaran. Pembelajaran berbasis tehnologi idealnya memiliki sistem manajemen pembelajaran (learning management system), karena pembentukan manajemen mempunyai beberapa fungsi sesuai yang dikemukakan oleh Terry (1986) yaitu perencanaan,pelaksanaan,evaluasi dan pengawasan. Dengan kesiapan dan perencanaan yang matang pembelajaran akan dapat dilaksanakan secara efektif dan efesien.

\section{Kompetensi Pengelolaan Pembelajaran daring}

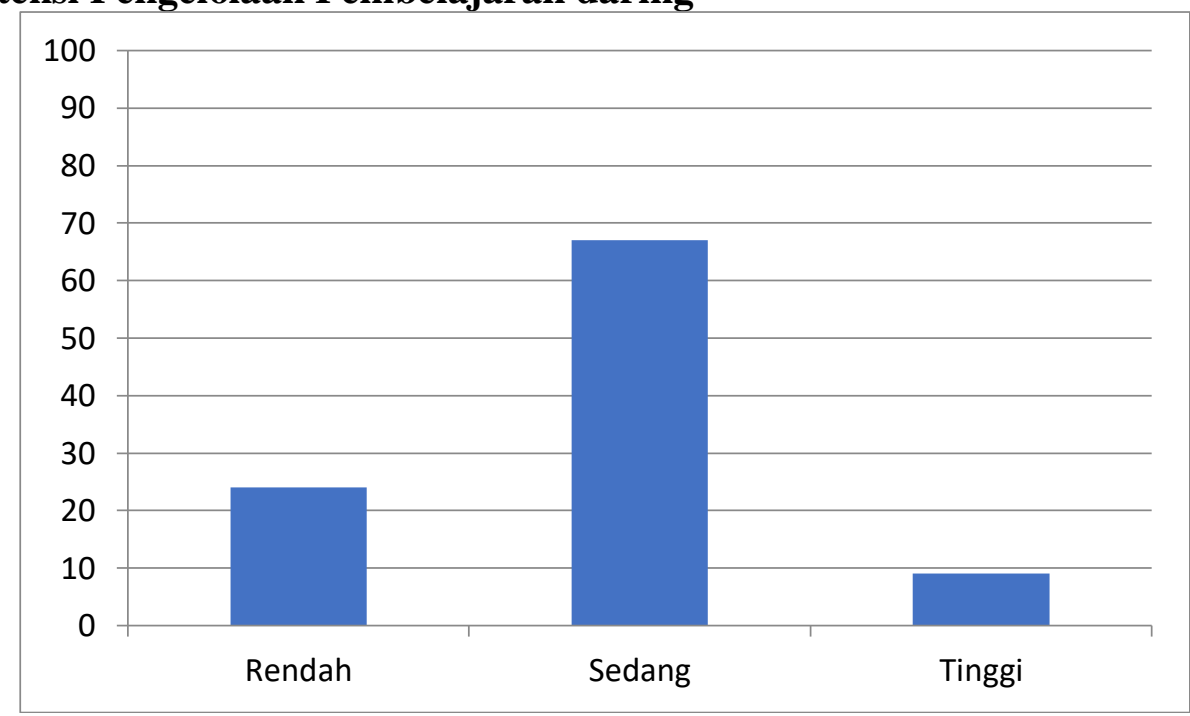

Gambar 3. Kompetensi Pengelolaan Pembelajaran daring

Pada gambar 3. Merupakan perolehan data tentang kompetensi pembelajaran daring di Madrasah Ibtidaiyah Kecamatan Reban bahwa 24\% rendah, 67\% sedang dan 9\% yang memiliki kompetensi tinggi. hal ini menggambarkan bahwa kemampuan guru untuk mengelola pembelajaran daring belum sepenuhnya menguasai bahkan masih ada yang baru tahap belajar.

Sekilas pembelajaran daring nampak begitu mudah dan menyenagkan ,namun pada praktiknya penggunaan aplikasi sebagai pengganti kegiatan belajar mengajar tatap muka secara langsung banyak menghadapi kendala dan hambatan. Guru sebagai fasilitator pembelajaran hendaknya lebih dulu menguasai tehnologi pembelajaran daring dari pada peserta didik. Menurut Mulyana et.al (2020) Transformasi cepat model pembelajaran konvensional tatap muka menjadi pembelajaran daring yang bertumpu pada penguasaan tehnologi komunikasi dan informasi mengharuskan guru meningkatkan kompetensi paedagogik secara cepat atas penguasaan tehnologi tersebut untuk mendukung pembelajaran virtual atau berbasis daring.

Sebagai solusi terhadap rendahnya kompetensi pengelolaan pembelajaran daring perlu mengikuti Bintek Teknis penggunaan aplikasi dan penguasaan tehnologi lainnya.

\section{Infrastruktur Pembelajaran daring}

Perangkat utama yang harus ada agar pembelajaran berbasis virtual atau daring yaitu adanya akses jaringan internet dan tersedianya gawai bagi guru dan siswa.

Tabel 1. Akses Jaringan Internet

\begin{tabular}{lll}
\hline No & Kriteria & $\begin{array}{c}\text { Dalam } \\
\text { Persen }\end{array}$ \\
\hline 1. & Sukar & 67 \\
2. & Sedang & 21 \\
3. & Mudah & 12 \\
\hline
\end{tabular}


Pada Tabel 1. Menggambarkan akses jaringan internet di Madrasah Ibtidaiyah Kecamatan Reban. Kriteria sukar 67\%, sedang 21\%, mudah 12\% . kondisi ini dipengaruhi oleh banyak faktor antara lain letak geografis Kecamatan Reban banyak perbukitan dan lembah sehingga koneksi jaringan tidak stabil bahkan beberapa tempat tidak ada jaringan sama sekali.

Kemudian ketersediaan gawai bagi siswa baru $80 \%$ sisanya pinjam saudara . sedangkan semua guru telah memiliki gawai namun dari segi kualitas masih jauh dari harapan. Dengan kata lain Infrastruktur pembelajaran daring kurang memadai.

Hasil penelitian di atas sejalan dengan (Kemendikbud,2020) yang menyatakan bahwa meskipun jaringan internet dalam genggaman tangan, peserta didik menghadapi kesulitan akses jaringan internet karena tempat tinggalnya di daerah pedesaan, terpencil dan tertinggal. Kalaupun ada yang menggunakan jaringan seluler terkadang jaringan yang tidak stabil, karena letak geografis yang masih jauh dari jangkauan sinyal seluler. Hal ini juga menjadi permasalahan yang banyak terjadi pada peserta didik yang mengikuti pembelajaran daring, sehingga pelaksanaannya kurang efektif.

Kesenjangan infrastruktur pembelajaran daring tidak semata-mata menjadi tanggungjawab praktisi pendidikan akan tetapi peran serta pemerintah untuk menjamin ketersediaan akses jaringan internet merata ke seluruh wilayah tanah air baik perkotaan maupun daerah terpencil sekalipun.Sedangkan penyediaan gawai untuk siswa yang berkualitas perlu adanya koordinasi antar orang tua siswa dan stakeholder.

\section{Keaktifan Siswa Mengikuti Pembelajaran}

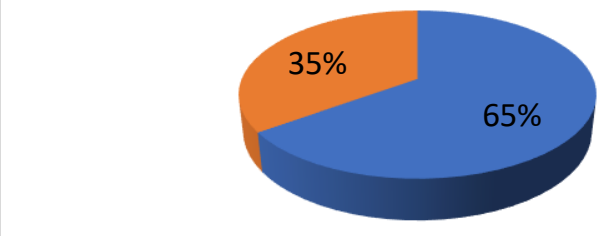

Siswa Aktif

\section{Gambar 4. Keaktifan Siswa Mengikuti Pembelajaran}

Gambar 4. Memberi informasi bahwa siswa yang aktif mengikuti moda pembelajaran daring ada $65 \%$ sisanya $35 \%$ tidak aktif. Siswa yang tidak aktif disebabkan oleh beberapa kendala yaitu sinyal celluler yang tidak stabil, kehabisan kuota internet, handphone di bawa orang tua ,kapasitas handphone tidak mencukupi dan kejenuhan siswa dalam belajar.

Keaktifan siswa dalam kegiatan belajar mengajar berbasis internet merupakan salah satu tolak ukur kompetensi guru atas penguasaan tehnologi pembelajaran (EduTech). Guru yang menguasai edutech dan literasi digital tentunya dapat membangkitkan motivasi dan minat siswa untuk aktif belajar. Kejenuhan siswa tatkala pembelajaran daring bersifat monoton seperti penugasan dan mencatat materi terus menerus. Menurut Elliott (dalam Aini 2020) mengemukakan bahwa karakteristik siswa,karakteristik guru,performance (kinerja) guru dalam mengajar merupakan beberapa faktor yang dapat mempengaruhi keaktifan siswa dalam kegiatan belajar mengajar.

Kegiatan workshop, diklat teknis subtantif tentang literasi digital menjadi solusi yang tepat untuk membekali guru agar moda pembelajaran daring dapat dilaksanakan secara efektif. 


\section{Penerapan Strategi Pembelajaran}

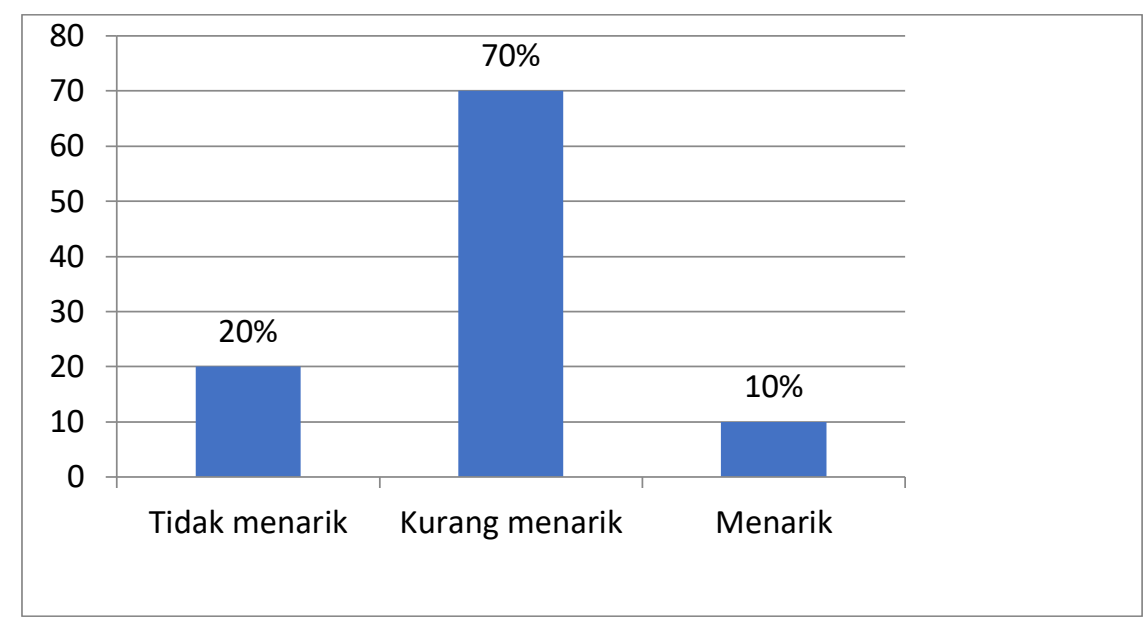

Gambar 5. Penerapan Strategi Pembelajaran

Hasil penelitian tentang penerapan strategi pembelajaran saat daring di Madrasah Ibtidaiyah Kecamatan Reban seperti tampak pada gambar 5. Kasus yang muncul ditengah pembelajaran daring hanya $10 \%$ menarik,70\% kurang menarik dan $20 \%$ tidak menarik. Hal ini berarti bahwa pola pembelajaran belum dirancang dan dikemas secara baik ,praktik di lapangan guru memberi tugas dan penyampaian materi secara lenier dengan mengunggah foto materi pelajaran dan latihan soal pada buku /bahan ajar berulang-ulang. Baru sebagian kecil yang menerapkan strategi pembelajaran secara variatif dikemas menggunakan animasi, quiz, power point,zoom meeting dan video call.

Penerapan strategi pembelajaran sangat penting baik dalam proses pembelajaran tatap muka secara langsung maupun pada moda pembelajaran daring dalam rangka mencapai tujuan pembelajaran yang efektif dan efisien.Menurut Nasution (2017:5) Strategi pembelajaran adalah keseluruhan pola umum kegiatan pendidik dan peserta didik dalam mewujudkan peristiwa pembelajaran yang efektif untuk mencapai tujuan oleh paduan urutan kegiatan ,metode dan media pembelajaran serta waktu yang digunakan dalam kegiatan tersebut.

Untuk meningkatkan kompetensi guru dalam upaya menerapkan strategi pembelajaran yang variatif,kreatif dan inovatif dengan memanfaatkan kegiatan KKG guru kelas menghadirkan nara sumber yang relevan dan berkompenten.

\section{Pengawasan Pembelajaran daring}

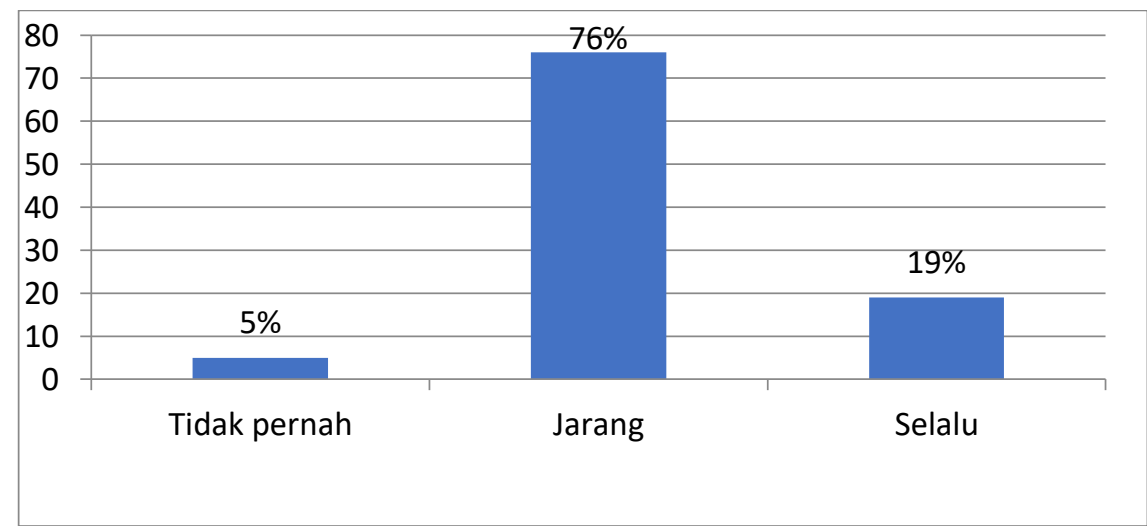

Gambar 6. Pengawasan Pembelajaran daring

Penggunaan gawai bagi peserta didik untuk interaksi belajar mengajar merupakan sesuatu yang baru ,fungsi pengawasan menjadi hal yang penting agar supaya proses belajar mengajar berlangsung efektif dan tepat sasaran. Dari gambar 6. Diperoleh informasi $19 \%$ selalu 
diawasi, sedangkan sebagian besar jarang pengawasan yaitu $76 \%$ dan sisanya $5 \%$ tidak pernah ada pengawasan.

Fakta di lapangan pada tahap awal pelaksanaan pembelajaran daring menjadi perhatian semua pihak termasuk orang tua turut mendampingi dan memantau pembelajaran ,namun seiring berjalannya waktu pengawasan mulai pudar karena banyak menyita waktu dan kejenuhan mulai dirasakan.

Peran sebagai guru tidak lagi hanya membimbing anak belajar,akan tetapi juga membimbing orang tua agar dapat membantu mendampingi anak belajar di rumah dengan maksimal.Menurut (Bari,S et al.2020) Bahwa pendidikan sebagai hak anak, menjadi tanggung jawab bersama yang dipikul oleh sekolah, orang tua dan masyarakat, serta menjadi kewajiban negara melalui sekolah dan dinas pendidikan.

Agar kegiatan pembelajaran daring berlangsung efektif perlu adanya kolaborasi sistem pendampingan dan pengawasan dari guru, orang tua ,komite sekolah dan masyarakat serta instansi terkait secara intensif dan konsisten.

\section{Kondisi Psikologis Pendidik Dan Peserta Didik}

Fakta di lapangan pemberlakuan WFH/WFO yang berkepanjangan telah mempengaruhi kondisi psikis bagi guru di Madrasah Ibtidaiyah Kecamatan Reban pada saat melaksanakan pembelajaran daring ,beban moral mulai terasa ketika banyak materi pembelajaran yang tidak tersampaikan secara optimal karena alokasi waktu yang dibatasi,belum lagi tugas-tugas yang diberikan kepada siswa tidak kunjung dikerjakan, pekerjaan menumpuk dan tidak sedikit keluhan orang tua yang disampaikan ketika mendampingi anaknya belajar. Kondisi ini tidak jauh berbeda pada peserta didik,merasakan kejenuhan pada saat daring, banyaknya tugas dari guru,kurang memahami materi yang disampaikan, koneksi jaringan internet yang lambat,waktu bersosialisasi kepada teman dibatasi,beban tugas sebagian dilimpahkan kepada kakak atau orang tua sehingga kemandirian siswa untuk belajar berkurang beralih pada ketergantungan pada orang lain.

Dari kenyataan kondisi psikologis pendidik dan peserta didik tersebut menunjukkan bahwa moda pembelajaran daring yang pelaksanaanya dipaksakan tanpa perencanaan yang matang kurang efektif. Hal ini sejalan dengan hasil penelitian (Pakaya,Kida \& Atas,2020) menunjukan bahwa pembelajaran online kurang efektif, karena ada beberapa mata pelajaran yang sulit dipahami apalagi melihat setiap anak memiliki latar belakang dan psikologis yang berbeda-beda apabila dilihat dari segi sikap atau perilaku siswa.

\section{KESIMPULAN}

Moda pembelajaran daring yang menggunakan tehnologi informasi dan komunikasi dipandang sebagai moda pembelajaran yang lebih efektif dan efisien sehingga diharapkan dapat menggantikan pembelajaran tatap muka secara langsung. Fakta di lapangan menunjukkan efektivitas pembelajaran daring yang dilaksanakan di Madrasah Ibtidaiyah Kecamatan Reban bisa dikatakan belum berjalan efektif karena dipengaruhi oleh beberapa faktor yaitu kurangnya kesiapan penerapan moda pembelajaran daring,kompetensi pengelolaan pembelajaran daring yang kurang maksimal,infrastruktur pembelajaran daring kurang memadai,kurangnya keaktifan siswa mengikuti pembelajaran,penerapan strategi pembelajaran kurang menarik,rendahnya pengawasan dan kondisi psikologis yang kurang mendukung akibat transformasi cepat dan mendadak. Oleh karena itu daya dukung yang ada harus dioptimalkan agar pembelajaran daring lebih efektif dan efisien serta bermanfaat untuk meningkatkan kualitas pendidikan.

\section{DAFTAR PUSTAKA}

Al Halik \& Aini,Z. (2020). Analisis Keaktifan Siswa dalam Proses Pembelajaran Daring di Masa Pandemi COVID-19. Enlighten: Jurnal Bimbingan Konseling Islam.from m Vol. 3 No. 2 : 131-141 
Arikunto,S. (2009). Dasar-dasar Evaluasi Pendidikan. Jakarta: Aneka Cipta

Keputusan Bersama Menteri Pendidikan dan Kebudayaan, Menteri Agama, Menteri Kesehatan dan Menteri Dalam Negeri No. 01/KB/2021, No. 516 Tahun 2020, No. HK.03.01/Menkes/363/2020, dan No. 440-882 tentang Panduan Penyelenggaraan Pembelajaran pada Tahun Ajaran 2020/2021 dan Tahun Akademik 2020/2021 di masa Covid-19

Ma'arif,S. (2011). Guru Profesional Harapan \& Kenyataan. Semarang : Need's Press

Mulyana,dkk. (2020). Pembelajaran Jarak Jauh Era Covid-19, Karya Tulis.Jakarta: Balai Penelitian dan Pengembangan Agama

Nasution ,W.N. (2017). Strategi Pembelajaran. Jakarta : Perdana Mulya Sarana. ISBN 978602-6462-90-9

Nurdyansyah. (2019). Media Pembelajaran Inovatif. Sidoarjo Jawa Timur : Umsida Press. ISBN: 978-602-5914-71-3

Pakaya,N.,Kida,F.A \& Atas,W. (2020). Dampak Media Pembelajaran Online Pada Pendidikan Islam MTs Al-Muhajirin Manado Dalam Prespektif Psikologi Anak Di Era Covid-19. JIVA: Journal of Behavior and Mental Health E-ISSN : 2723-4363 Vol. 1. No. 2 : 71 75

Rijali, A. (2018). Analisis Data Kualitatif. Jurnal Alhadharah Vol.17 No.33 hal.83

SE Sekretaris Daerah Kabupaten Batang 2021 Nomor : 800/096/2021 tanggal 2 Juli tentang sistem kerja pegawai Aparatur Sipil Negara di lingkungan Kabupaten Batang.

Terry,G.R. (1977). Program Learning Aid: Principles Of Management Illions: Richard, D.Irwinn, Inc. 